\title{
THE ROLE OF MEDICAL EDUCATORS- PERCEPTION OF INDIAN MEDICAL STUDENTS
}

\author{
Pia Muriel Cardoso ${ }^{1}$, Christo Fernandes ${ }^{2}$
}

${ }^{1}$ Associate Professor, Department of Obstetrics and Gynaecology, Goa Medical College, Goa, India.

${ }^{2}$ Associate Professor, Department of Human Resources, Goa Institute of Management, Goa, India.

\section{BACKGROUND}

\section{ABSTRACT}

An educator is someone who not only teaches but influences an individual as well. He/she offers direction, mentorship, career counselling, coaching and introspection; provides feedback and helps in moulding an individual's personality. Given the importance of formal educators and the influence they have in moulding young Indian individuals, there is need for research which can cover this aspect of education.

The perception a student has of an ideal educator, the factors influencing behaviour and the role of the educator in shaping the backbone of an individual were the key objectives of our study.

\section{MATERIALS AND METHODS}

This is a descriptive study. Fifty students from the final year MBBS course at Goa Medical College participated in a qualitative study comprising of a one-on-one in-depth personal interview. This study helped to identify different role expectations of students from medical educators, the impact of student's experiences on their current perception of an "Ideal Medical Educator" and the influence of teacher's guidance on various areas of a medical student's life.

\section{RESULTS}

Our study reveals that the notion of a medical educator from the student's perspective evolves over time from being recognised as a mere source of knowledge to being accepted as an all-round facilitator. Qualities appreciated highly by students in a medical educator were approachability, depth of knowledge, communication skills and ability to unleash creativity.

\section{CONCLUSION}

Students seek a facilitator role from teachers in deciding their career path and want them to promote an environment of independent thinking. The findings of this study could provide insight into areas of medical education, which could be positively influenced by a good educator.

\section{KEY WORDS}

Medical Educators, Medical Students, Medical Education.

HOW TO CITE THIS ARTICLE: Cardoso PM, Fernandes C. The role of medical educators- perception of Indian medical students. J. Evolution Med. Dent. Sci. 2018;7(40):4371-4376, DOI: 10.14260/jemds/2018/975

\section{BACKGROUND}

A lot of people hold the designation of a teacher, but few enjoy the credentials of an educator. An educator is someone who not only teaches, but influences an individual as well. $\mathrm{He} / \mathrm{she}$ offers direction, mentorship, career counselling, coaching and introspection; provides feedback and helps in moulding an individual's personality.

According to Griffin,(1) teaching is a process which is constantly under constraint. The perceptions of the teacher influence his/ her teaching. The narrower the perception, the more restricted is the teaching. There is need to redefine the guiding principles of teaching in context of today's learner generation.

There is one area of research which states that an educator can play two roles, one is the role of a teacher whose main challenge is to learn and think in context to the demands of teaching(2) and the other role is of a mentor which is of a highly interpersonal nature and takes place in the vocational setting.(3)

'Financial or Other Competing Interest': None

Submission 07-08-2018, Peer Review 15-09-2018,

Acceptance 21-09-2018, Published 01-10-2018.

Corresponding Author:

Dr. Pia Muriel Cardoso,

Department of Obstetrics and Gynaecology,

Goa Medical College.

E-mail: pmcardoso30@yahoo.co.uk

DOI: $10.14260 /$ jemds $/ 2018 / 975$

\section{(c) $(1)$}

Ferrar(4) has highlighted the impracticality behind the approach of separating the two roles from each other.

By following innovative teaching practices like open book examinations, collaborative form of assessment and research projects as per unique requirements of individual students, educators can promote more academic integrity, team work, creative thinking and encourage a healthy competitive spirit in the classroom. (5)

The medical education system in India is more theory oriented rather than practically applicable. There exists a need to redesign the system, so that it can evaluate learning outcome not only based on examination marks but on the basis of other innovative measurable parameters.

The influence of an educator on an Indian student has been prevalent since time immemorial. It goes back to the Indian model of Guru-Shishya. The guru is a guide or teacher and the shishya is the student he takes under his wing. The guru acts as a knowledge source and shishya has the opportunity to get fully trained and yet shoulders the responsibility for his own art form.(6)

A change in the educator's perception can bring about change in the level of student's motivation towards progress and learning. An educator should know the influential factors of his/ her teaching practices on student's lives and this may help in determining effective teaching behaviour.

Given the importance of formal educators and the influence they have in moulding young Indian individuals, there is need for research which can cover this aspect of 
education. The perception a student has of an ideal educator, the factors influencing behaviour and the role of the educator in shaping the backbone of an individual were the key objectives of our study.

\section{MATERIALS AND METHODS}

\section{Sample}

The participants in the study comprised a sample of 50 MBBS students (25 males and 25 females) from Goa Medical College.

\section{Inclusion Criteria}

Students pursuing graduate studies currently in their final year. All students were of Indian Origin.

\section{Tools/ Materials}

A semi-structured interview template comprising of research questions.

\section{Procedure}

A pool of medical students meeting the inclusion criteria for the study was created and the sample of 25 males and 25 females was randomly drawn.

Written informed consent was obtained from medical students selected for the study including permission for audio recording of the interviews. The interviews were conducted by a panel of two investigators- one of whom administered the questions and the other who recorded the proceedings. This panel remained constant for each interview throughout the study. Subsequently, the interview template including questions were administered. Each interview was transcribed and the data was analysed using content analysis methods.

While conducting every interview, respondents were given a brief description of the research study and its aim. There is a possibility that respondent's answers can reflect their opinions or judgements rather than true experience. To avoid such a scenario, further probing of respondents was done by the interviewers as per the situation. Confidentiality was ensured.

\section{Content Analysis}

The procedure followed is the one suggested by Glaser,(7) Krippendorf(8) and Weber.(9) All comments of research applicability were selected and grouped into major themes. The main purpose behind following this approach was to reflect the core meaning of respondent statements. Statements with unique ideas were reflected in the content analysis, but repetition of the same ideas was avoided.

An inductive approach was followed for content analysis where individual comments were grouped into possible dimensions. Keywords of statements have also been used as a criterion for identification of suitable dimensions. Further, dimensions were clubbed into major themes based on the underlying meaning.

\section{RESULTS}

1. How would you describe your Experience of the Indian Medical Educational System so far?

Interviewees made 84 statements in response to the question "How would you describe your experience of the medical educational system so far?" These 84 statements were characterised into 31 dimensions, which were further grouped into 6 major themes.

Experience defined by- 1) Use of Knowledge and Delivery Methodology, 2) Overall impact on Personal Development, 3) Change in the System, 4) Outcome Orientation, 5) Impact of Teaching process, 6) Scope for Change.

\section{Respondents mostly described their Experiences}

1. Restricted to theoretical knowledge and rote learning (14\%).

2. The learning is highly academic and performance oriented (11\%).

3. The learning environment is highly competitive and there is a need for change in the medical education system (18\%).

\begin{tabular}{|c|c|}
\hline Dimension (Number of Statements) & Sample Statements \\
\hline \multicolumn{2}{|l|}{$\begin{array}{l}\text { Experience defined by knowledge use and } \\
\text { delivery methodology }\end{array}$} \\
\hline Focus on theory & \begin{tabular}{|c|} 
Too much emphasis on textbook based assessment \\
\end{tabular} \\
\hline Rote learning & The curriculum unfortunately focuses more on repetition rather than reasoning \\
\hline Remembering classroom information & You never take more than $20 \%$ of your learning back home \\
\hline Forced to answer tests repeatedly & Had to do compulsorily, this put pressure on us constantly \\
\hline \multicolumn{2}{|l|}{$\begin{array}{c}\text { Experience defined by overall impact on } \\
\text { personality development }(10)\end{array}$} \\
\hline Overall development & They actually give their students a more holistic approach to everything \\
\hline Personality development & Basically, this was all in preparation to get you ready for challenges \\
\hline \multicolumn{2}{|l|}{ Experience defined by change in the system(11) } \\
\hline \begin{tabular}{|c|} 
Paradigm shift \\
\end{tabular} & Methodology has changed from normal to interactive \\
\hline Progressive change & $\begin{array}{c}\text { Education systems do not expect you to rote learn. They expect you to read } \\
\text { everything in and around the topic }\end{array}$ \\
\hline Challenges & Difficulty in adjusting to traditional methods \\
\hline Rigidness of system & Not different in this aspect \\
\hline \multicolumn{2}{|l|}{ Experience defined by outcome orientation(12) } \\
\hline Actual/ Real learning & $\begin{array}{c}\text { They do not expect you to rote learn, they expect you to read everything in and } \\
\text { around the topic }\end{array}$ \\
\hline $\begin{array}{l}\text { Performance oriented rather than learning } \\
\text { oriented }\end{array}$ & The learning has taken a back seat and you are just expected to perform \\
\hline
\end{tabular}




\begin{tabular}{|c|c|}
\hline Impractical & Lack of vocational skill learning \\
\hline Academically oriented & Make us study a lot \\
\hline Inhibit individual thinking & Cram everything and reproduce on paper, inhibits the student thinking \\
\hline \multicolumn{2}{|l|}{$\begin{array}{l}\text { Experience defined by impact of } \\
\text { teaching process }\end{array}$} \\
\hline Encouraging (towards your interest areas) & They always encouraged us to take part in extra-curricular activities \\
\hline Responsibility & You become grounded \\
\hline Enjoyable & $\begin{array}{l}\text { Once in a while we used to go for field trips and studies came as a second } \\
\text { priority, that is what I enjoyed most about the system }\end{array}$ \\
\hline Warm and friendly & System is rigid, but at the same time it is very warm, friendly and welcoming \\
\hline Taught hard working & Where since childhood we are taught to be very hard working \\
\hline Irrelevant & What is the relevance of those old medical concepts in today's world? \\
\hline Boring/ Monotonous & It was very monotonous, just rote learning and tests \\
\hline Competitive & I had to compete for marks, you have to perform to the highest level \\
\hline Overbearing & Most of the time you are just over-worked \\
\hline Disciplined & $\begin{array}{l}\text { Too much discipline } \\
\end{array}$ \\
\hline No seriousness/ No dedication & Let alone the students, even the teachers are not serious about studies \\
\hline \multicolumn{2}{|l|}{ Experience defined by scope for change } \\
\hline Overall change need & I think the medical education system does need an overall change in that sense \\
\hline Overall learning & Need of an overall education, not just study \\
\hline Opportunity to explore & Student should be given more opportunity to explore extracurricular activities \\
\hline Assessment fallacy & $\begin{array}{l}\text { The assessment method needs to change } \\
\end{array}$ \\
\hline \multicolumn{2}{|c|}{ Table 1. Experience of Medical Education System } \\
\hline
\end{tabular}

\section{Describe the Characteristics of an Ideal Medical Educator based on Your Experience?}

Interviewees made 78 statements in response to the question "What, in your opinion, are the characteristics of an ideal educator?" These 78 statements were characterised into 29 dimensions, which were further grouped into 4 major themes.

Characteristics are divided as- 1) Work related traits, 2) Personality traits, 3) Behavioural traits, 4) Facilitator toward overall growth.

Interviewees mostly described their Ideal Educator to be-

1. A follower of practical approaches, someone who uses live examples (11\%).

2. An effective teacher and an engager (13\%).

3. An effective communicator who follows innovative techniques (10\%).

4. Facilitator towards overall growth (16\%).

\begin{tabular}{|c|c|}
\hline $\begin{array}{c}\text { Dimensions } \\
\text { (Number of Statements) }\end{array}$ & Sample Statements \\
\hline \multicolumn{2}{|l|}{ Work related traits } \\
\hline Committed toward the subject & He should be committed and passionate about the subject \\
\hline Teach via live examples & $\begin{array}{l}\text { When your educator comes up with more of personal experiences and relatable things, } \\
\text { students relate to it }\end{array}$ \\
\hline Provides feedback & They should give a class feedback at least once a week \\
\hline A two-way communicator & He should learn from students also \\
\hline Follow practical approach & Should not give theoretical knowledge only \\
\hline Who promotes constructive learning & Idea is that there should be constructive learning \\
\hline Good content planner & $\begin{array}{l}\text { Good educator according to me is someone who has tried to gauge what is the prior } \\
\text { learning of the student and then designed their curriculum in that way }\end{array}$ \\
\hline Knowledgeable & He should be very knowledgeable about his subject \\
\hline Audience centric approach & He should try to find a very simple way to explain it, the way the students will understand \\
\hline \multicolumn{2}{|l|}{ Behavioural traits } \\
\hline Talent recogniser & He should try and identify talents in each student and which is the best role for them \\
\hline Innovator & $\begin{array}{l}\text { An ideal educator never just uses bookish knowledge to teach a class, they use different } \\
\text { kinds of methods }\end{array}$ \\
\hline Engager & An educator has to be very engaging and interactive \\
\hline Effective communicator & Should be able to impart the knowledge very well \\
\hline Approachability & Students should be able to approach him without fear \\
\hline Interactive & If you have a monotonous educator, it becomes very boring for the student \\
\hline Effective teacher & Effective teacher would be someone who will create interest in subject \\
\hline Encourager & They understood students at every age and actually encouraged them to explore the world \\
\hline \multicolumn{2}{|l|}{ Personality traits } \\
\hline Friendly & $\begin{array}{l}\text { We had a very close and friendly relationship with teachers. They were more of elder } \\
\text { brothers rather than teachers }\end{array}$ \\
\hline
\end{tabular}




\begin{tabular}{|c|c|}
\hline $\begin{array}{c}\text { Who can develop a social bond } \\
\text { Unbiased }\end{array}$ & $\begin{array}{c}\text { That is what I call an ideal educator, someone who is with the student throughout the day } \\
\text { I think bias is something that should not be there, favouritism should not be there amongst } \\
\text { educators }\end{array}$ \\
\hline Trustworthy & Must be able to build a relationship of trust with his students \\
\hline Respect student & Ideal educator should respect students \\
\hline Caring & He should be warm and caring \\
\hline Open minded & I think an educator should not maintain a closed perspective \\
\hline Well behaved & Also, equally who knows how to treat students well \\
\hline Empathetic & The educator must have empathy toward students of diverse backgrounds and cultures \\
\hline $\begin{array}{c}\text { Facilitator towards overall } \\
\text { growth(13) }\end{array}$ & If you really want to make a difference to somebody, you have to be more than a teacher \\
\hline Act as a Mentor & Ideal educator should direct group and take everyone together \\
\hline Direct group towards a goal & Not just studies but be a guide in more than one area of assistance \\
\hline Help in overall development & Table 2. Characterisation of an Ideal Medical Educator \\
\hline \multicolumn{2}{c}{} \\
\hline
\end{tabular}

\section{Describe the Attributes of some of the Educators that you have encountered?}

Interviewees made 70 statements in response to the question- "3) Describe the attributes of some of the educators that you have encountered?"

These 70 statements were characterised into 29 dimensions, which were further grouped into 6 major themes.

Attributes are classified into- 1) Accommodating Approach, 2) Casual Approach, 3) Structural Approach, 4) Engaging Approach, 5) Behavioural Approach and 6) Realistic Approach.

\section{Interviewees mostly described their Encountered Educator Attributes as them being-}

1. Systematic, theoretical and restricted in their approach (20\%).

2. Strict, disciplined and closed minded (18\%).

3. Those who observed educators following a realistic approach (14\%).

4. Accommodating and approachable (14\%).

\begin{tabular}{|c|c|}
\hline $\begin{array}{c}\text { Dimensions (Number of } \\
\text { Statements) }\end{array}$ & Sample Statements \\
\hline \multicolumn{2}{|l|}{ Accommodating approach(14) } \\
\hline Good listener & Any ideas you have, the professors are ready to listen to it \\
\hline Open-minded & He was open and gave me proper time \\
\hline Helpful & They will give you some inputs and feedback and even refine your ideas \\
\hline Two-way communicator & She provided us with good feedback \\
\hline Relatable & In college also, there were a lot of younger faculties who were more relatable \\
\hline Approachability & $\begin{array}{l}\text { At any point in time if we had any issues; homesickness besides studies, we could speak to } \\
\text { someone }\end{array}$ \\
\hline \multicolumn{2}{|r|}{ 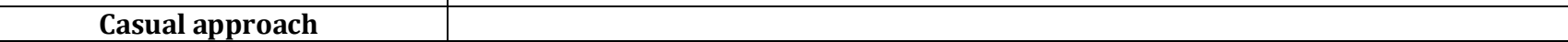 } \\
\hline Carefree attitude and lenient & Teachers who have been so lenient that they do not really care what you do in class \\
\hline \multicolumn{2}{|l|}{ Structural approach } \\
\hline Systematic & She was one of the most systematic \\
\hline Disciplined & Most disciplined and very smart woman I have ever met \\
\hline Target oriented & But a lot of times I see that teachers are more focused on achieving their targets \\
\hline Restrictive in teaching approach & $\begin{array}{c}\text { They should not restrict themselves and try to have a very comprehensive view of the } \\
\text { learning }\end{array}$ \\
\hline Theoretical & $\begin{array}{l}\text { They taught bookish knowledge } \\
\end{array}$ \\
\hline Strict & I have met teachers who have been extremely strict \\
\hline Close-minded & They kind of force their techniques of problem solving on you \\
\hline \multicolumn{2}{|l|}{ Engaging approach } \\
\hline Interactive and Fun & Lot of teachers were always very interactive, they had lot of role play \\
\hline Impactful & They shared their personal experiences, the challenges they have taken \\
\hline Facilitator & Every teacher tries to put confidence in their students to get them to come out of their shell \\
\hline \multicolumn{2}{|l|}{ Behavioural approach(15) } \\
\hline Empathetic & The educators in medical school were not all empathetic \\
\hline Sympathetic & The educators in my medical school were sympathetic \\
\hline Manager & Educators are in the role of a manager, they will grill you \\
\hline Diligent & He provided me with different ways to solve the problem \\
\hline Responsible & We felt that Teachers are responsible for us \\
\hline Caring & There was medical teacher who used to be very loving and caring \\
\hline Good communicator & His communication skills were so good that students never bunked his lectures \\
\hline Honest & That particular teacher was very honest \\
\hline \multicolumn{2}{|l|}{ Realistic approach(16) } \\
\hline Application oriented & Make students understand about the practical aspects \\
\hline
\end{tabular}




\begin{tabular}{|c|c|}
\hline Directional & He gives me proper direction \\
\hline Contributor & Who I think is a really good educator is who really contributed to my learning \\
\hline Encourager & They would pick up on talent and encourage you to do good stuff \\
\hline \multicolumn{2}{|c|}{ Table 3. Encountered Indian Medical Educator's Attributes } \\
\hline
\end{tabular}

\section{DISCUSSION}

This study examined the relationship dynamics of medical educators and students. The study aimed at exploring the influence of medical educators in context of student's past experience with teachers. Although, the study addressed many areas, we will discuss some findings which have possible significance in the context of the present study.

Findings coherent with earlier research.

Respondent's perceptions and expectations of a medical educator's role and their experience with past educators reveal certain findings, which are similar to findings of previous research. Respondents have identified certain attributes of medical educators, which could make them facilitators towards overall growth like Personal Goal Motivator, a Talent Searcher and Career Strengths Identifier. Students feel that development of such attributes can make a medical educator more of a facilitator rather than only a teacher. Some of these findings have been discussed in previous research studies. Salter and Gannon(17) stated that mentors of young people have to understand the needs of young people and adopt a non-directive approach. When respondents were asked about the importance of the role of educators in their career path, students were of the opinion that medical educators influence their career in two ways, one by acting as a moulder who helps in identifying their strengths and finds hidden talents in them and the other by acting as a career guide and knowledge source. This finding is similar to the findings of Scanlon(12) and Weinberger(14) who stated that beyond a relationship of trust, teacher and student are enrolled in a career path decider relationship. Their research findings state that teachers are not only mentors, but they play a greater role as compared to a mentor in any student's life. Similar findings have been revealed in this research study. Medical students perceive their educators as not only a knowledge source, but as facilitators towards overall growth.

The research study reveals that medical students have experienced more theory based learning in their school phase. Emphasis was given more to grades and marks rather than self-learning and application. Respondents have described their encountered medical educator's attributes as systematic, theoretical and restricted. Findings have revealed that medical educators with a more accommodating and application based approach have more positive influence on overall growth of a student. A medical educator can modify his/ her approach to act as a facilitator toward overall development of a student.

In the following sections, we elaborate on the research study findings that suggests a dynamic influence of medical educators on students. This is in context of student's perception of an ideal medical educator and student's past experience with Indian medical educators and the Indian medical education system.

Student's past experience with medical education system and student's perception of an Ideal Medical Educator

Student's experience with the medical educational system was defined by methodology used by the medical educator to deliver the knowledge and its overall impact on student's development. The Indian medical education system promotes performance based learning and the learning environment in this system is highly competitive and academically oriented.

Past experiences of students with this education system has certainly influenced the perception of students toward an ideal medical educator. Findings revealed that the ideal medical educator should act as a facilitator towards overall growth and should follow innovative teaching methodologies to generate relevant interest in his/her subject. There is one area of research, which states similar findings. It states that one role of a medical educator is to learn and think in context of demands of teaching(18) and the other role is of a mentor which is of a highly interpersonal nature. This role of the educator acts as a facilitator towards overall development of a student and has been recognised as the most favourable attribute of an ideal medical educator by the respondents of our study.

Role of an Educator in deciding the Career Path of a Student (Based on Student's Perception)

Findings revealed that a medical educator's role in the career path of a student is influenced by how student's perception is affected by encounters with some of the past educators in their life. Some of the findings also revealed a link between perceptions of a student formed as per their past encounters with educators and student's perception regarding educator's importance in deciding his/ her career path. Respondents who encountered closed-minded, strict and disciplined educators have experienced very little influence on their career path. $14 \%$ of the respondents who have encountered accommodating, friendly and approachable educators have realised major influence on their career decision making process.

An educator can determine effective teaching behaviour if he knows about the influential factors of teaching practices on students' lives.

\section{Student's Perceptions Regarding Educators over time} and the Desired Ideal Approach of an Educator

To identify desired behaviour in an ideal educator, respondents were asked to assume themselves to be the educator. As per majority of the respondents (16\%), making a class fun and interactive by means of innovative teaching methodology is the priority. Some of the respondents have also revealed that empathetic nature of an educator is one of the most desirable traits.

Most of the students who had experienced a disciplined and restrictive teaching methodology of educators in their school phase yearned for open, flexible and participative learning in their later phase. This finding can be seen as a further extension of the findings of a few research studies,(19) which we have come across that have clearly stated how students and teacher relationships change gradually over time. 


\section{CONCLUSION}

The current study was conducted on fifty medical students. Interview questions were designed to gain in-depth knowledge of the same. The areas which this qualitative research study covered were- student's experience with the Indian Medical Education System so far, how student's perception regarding educators evolved over time and what exactly students look for in an Ideal Medical Educator. This study revealed that Indian medical students believe that the learning environment in the current education system is highly competitive and the teaching approach is more achievement oriented. It came out as an important belief parameter of students that the present medical education system is restricted to theoretical knowledge and it promotes rote learning. Rote learning acts as an irritant to a person who is looking forward to value addition by means of education. Teaching methodology should inculcate practices of real learning assessment rather than performance evaluation.

Respondents mostly described their ideal educator as someone whom they could approach without any form of hesitation, someone who followed innovative and engaging teaching practices. The most important characteristic which some of the respondents described of an ideal educator were that he was passionate about his own subject and thus able to generate interest of his students. Perception of an ideal medical educator has developed in the minds of students after having certain good and bad experiences with educators in their lives. Some of the attributes of educators which students did not really appreciate were their strict nature and narrow mindedness. Students prefer an educator who can be more approachable and accommodating rather than a disciplined person with restrictive approach.

One of the most interesting findings of the study was how student's perceptions evolved gradually from school to college. The majority of respondents mentioned that the school environment was limited to classroom teaching. It was a form of one way communication. Theoretical learning was prevalent in school phase. But the perception of students changed once they moved into college where they felt that they preferred application based learning. Students realised the importance of two way communication between students and medical educators in college.

The study revealed that the majority of respondents have two types of belief patterns when it comes to the role of an educator in influencing a student's career path. One belief pattern suggests that students look forward to educators as career guides who can advise them about new opportunities, relevant specialities of future study, etc.

The other belief pattern suggests that students see medical educators as career moulders who can identify hidden talent and can help in leveraging these strengths.

A person understands the situation better when he has faced a similar situation himself. Respondents were asked about what they would do differently if they themselves were the medical educators. This question revealed some crucial answers like respondents would like to follow certain innovative teaching practices, which could promote high order individual thinking. This study is a small step towards identifying parameters which could explain the student's perception of an educator and how it evolves with the current medical education system.

\section{REFERENCES}

[1] Griffin GA. Teacher induction: research issues. Journal of Teacher Education 1985;36(1):42-6.

[2] Clark CM, Yinger RJ. Teacher planning. In: Calderhead J, edr. Exploring teacher thinking. London: Cassell Education Limited 1987.

[3] Howey KR. A conceptual map to guide the great city universities urban educator corps partnership initiative. 2001. http://w.w.wgcuedu.org/conceptualframework.doc.

[4] Ferrar P. Defying definition: competences in coaching and mentoring. International Journal of Evidence Based Coaching and Mentoring 2004;2(2):53-60.

[5] Hulsart R, McCarthy V. Educators' role in promoting academic integrity. Academy of Educational Leadership Journal 2009;13(4):49-60.

[6] Kashalkar SK. Comparitive study of ancient gurukul system and the new trends of Guru-Shishya Parampara. American International Journal of Research in Humanities, Arts and Social Sciences (AIJRHASS) 2013;2(1):81-4.

[7] Glaser BG. Basics of grounded theory analysis. Mill Valley, CA: Sociology Press 1992.

[8] Krippendorff K. Content analysis: an introduction to its methodology. 2nd edn. Thousand Oaks, CA: Sage Publications 2004.

[9] Weber RP. Basic content analysis. $2^{\text {nd }}$ edn. Newbury Park, CA: Sage Publications 1990.

[10] McLellan H. Situated learning perspectives. Englewood Cliffs, NJ: Educational Technology Publications 1996.

[11] Passmore J, Gibbes C. The state of executive coaching research: What does the current literature tell us and what's the next for coaching research? International Coaching Psychology Review 2007;2(2):116-28.

[12] Scanlon L. Graduate attributes and the transition to higher education. In: Hager P, Holland S, eds. Graduate attributes, learning and employability. Netherlands: Springer 2006: p. 125-48.

[13] Cristancho S, Varpio L. Twelve tips for early career medical educators. Medical Teacher 2016;38(4):35863.

[14] Weinberger S. The medical educator in the $21^{\text {st }}$ century: a personal perspective. Transactions of the American Clinical and Climatological Association 2009;120:239-48.

[15] Bok D. Universities in the marketplace: the commercialization of higher education. 2003. http://lst-iiep.iiep-unesco.org/cgi-

bin/wwwi32.exe/[in=epidoc1.in]/?t2000 =016843/(1 $00)$.

[16] Trower CA. A new generation of faculty: similar core values in a different world. Peer Rev 2010;12(3):2730.

[17] Salter T, Gannon JM. Exploring shared and distinctive aspects of coaching and mentoring approaches through six disciplines. European Journal of Training and Development 2015;39(5):373-92.

[18] Yinger RJ. Learning the language of practice. Curriculum Inquiry 1987;17(3):293-318.

[19] Gehlbach H, Brinkworth ME, Harris AD. Changes in teacher-student relationships. British Journal of Educational Psychology 2012;82(Pt 4):690-704. 